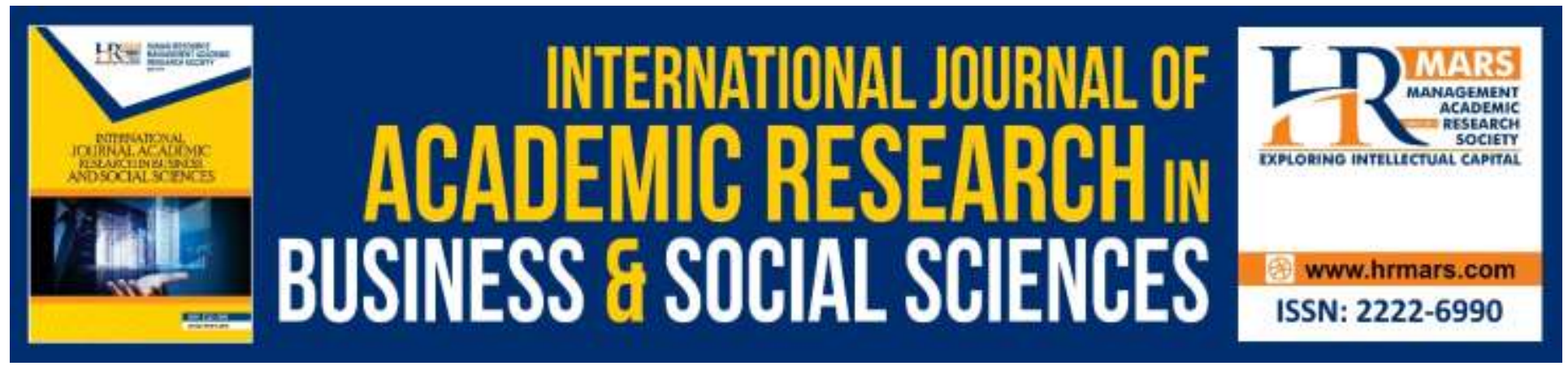

\title{
Liberalism between Acceptance and Rejection in Muslim World: A Review
}

Mohd Safri Ali, Shahirah Abdu Rahim, Aman Daima Md Zain, Mohd Hasrul Shuhari, Wan Mohd Khairul Firdaus Wan Khairuldin, Mohd Sani Ismail, Mohd Fauzi Hamat

To Link this Article: http://dx.doi.org/10.6007/IJARBSS/v9-i11/6600

DOI: 10.6007/IJARBSS/v9-i11/6600

Received: 13 October 2019, Revised: 30 October 2019, Accepted: 03 November 2019

Published Online: 21 November 2019

In-Text Citation: (Ali et al, 2019)

To Cite this Article: Ali, M. S., Rahim, S. A., Zain, A. D. M., Shuhari, M. H., Khairuldin, W. M. K. F. W., Ismail, M. S., Hamat, M. A. (2019). Liberalism between Acceptance and Rejection in Muslim World: A Review. International Journal of Academic Research in Business and Social Sciences, 9(11), 798-810.

Copyright: (C) 2019 The Author(s)

Published by Human Resource Management Academic Research Society (www.hrmars.com)

This article is published under the Creative Commons Attribution (CC BY 4.0) license. Anyone may reproduce, distribute, translate and create derivative works of this article (for both commercial and non-commercial purposes), subject to full attribution to the original publication and authors. The full terms of this license may be seen

at: http://creativecommons.org/licences/by/4.0/legalcode

Vol. 9, No. 11, 2019, Pg. 798 - 810

http://hrmars.com/index.php/pages/detail/IJARBSS

JOURNAL HOMEPAGE

Full Terms \& Conditions of access and use can be found at http://hrmars.com/index.php/pages/detail/publication-ethics 


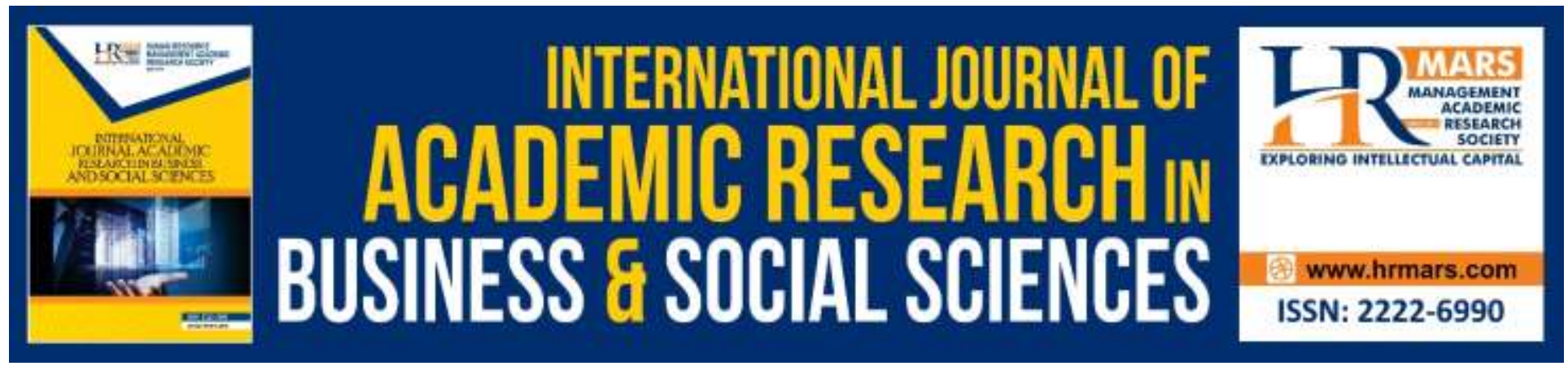

\title{
Liberalism between Acceptance and Rejection in Muslim World: A Review
}

\author{
Mohd Safri Ali, Shahirah Abdu Rahim, Aman Daima Md Zain, \\ Mohd Hasrul Shuhari, Wan Mohd Khairul Firdaus Wan Khairuldin, \\ Mohd Sani Ismail, Mohd Fauzi Hamat
}

Faculty of Islamic Contemporary Studies, Universiti Sultan Zainal Abidin, MALAYSIA

\begin{abstract}
The problem with ideology of liberalism and Islam remains its priority to the facet of the resolution of the Shari'a. Liberalism also seeks to loosen the rule of law and the rule of Islam rather than its adherents. This article reviews the literature on the concepts, acceptance and rejection of liberalism through the view of Muslim scholars. The objective of this article is to examine the concept of liberalism, acceptance and rejection of liberalism among Muslim scholars. In addition, the explanation of the intellectual views on liberalism is also highlighted. This article uses a qualitative approach with exploratory case study methods. Textual methods are applied to the information transferred therefore the information can be captured and interpreted. Data analysis is done by employing descriptive analysis. The findings show that there are acceptance and rejection of religious liberal ideology. Muslim scholars and independent intellectuals have also expressed their comprehensive views to wisely reject the ideology of religious liberalism as it is undoubtedly an apparent deviation from Islamic principles.
\end{abstract}

Keywords: General Literature Reviews, Religious, Liberalism, Muslim Scholar, Islamic Faith.

\section{Introduction}

If it is to be counted the threats of liberalism are precisely through the marginalization of Islamic fundamental teachings as a honourable way of life, rejecting religious rules and criticizing the shari'a which is considered a key barrier to human rights freedom (Sannusi \& Seman, 2018).

Beginning with the glorious era of Islamic revival, the essential issue of thought flow has become instantly a chosen topic of considerable debate among faithful Muslims. This is precisely because the potential flow of conscious thought naturally brings with it a proper mindset that aims to promptly challenge the purity of Islam. In contemporary terms the idea of a thought attack is also known as al-ghazw al-fikr or ideological reform (Mas'od, 2012). The attack of thought normally, 
focusing on destroying the people's faith on Islam in a country (Bakhit, 2011). This led to the emergence of new ideologies such as liberalism. The gradual emergence in liberating religious values certainly poses an imminent threat to the Muslim community as whole (Dagang, 2015).

Obviously, liberalism began to spread and influence the thinking of the people around the Muslim countries especially started on the twentieth and early $21^{\text {st }}$ century. This ideology has emerged consistently as a result of strong support from the Western Countries, especially the United States. According to Browers and Kurzman (2004), Asaf Ali Ashgar Fyzee was the first responsible individual to incorporate elements of liberalism into Islam. He has ironically named it as Liberal Islam. This idea has spawned his name. In fact, he was the first Muslim who contributed to modernise Islam and became the pioneer in modern Ismailiyya studies.

In Muslim countries, non-governmental organizations and educational foundations are used as effective agents for the excessive spreading of liberalism to the Muslim community (Zarif \& Abdullah, 2015). The direct result can be proven by the successful establishment of several organizations in Islamic countries such as the Liberal Islam Network in Indonesia (Majid, et.al 2011) and Sisters in Islam in Malaysia (Ibrahim et al., 2013). Controversial ideas that were raised by both organizations challenging the intellectual power of the Islamic scholars who endeavour to maintain the sanctity of religion (Rahim et al., 2016; Dollah, Zabit, \& Omar, 2018).

\section{Problem Statements}

Various published studies considered eagerly discuss about liberalism in the Muslim worlds. Among them are:

Azmi \& Ismail (2018) highlighted the legitimate demands of Nisya Ayub LGBT activists so that their social status was not discriminated against by the community in any cultural aspect. They should be granted the same opportunity and treated as members of the societies who enjoy the similar rights in a country.

The study of Ali and Ismail (2017) states the reader's opinion of religious liberalization in two news portals in Malaysia. Through the Berita Harian portal, all readers overwhelmingly agree to reject religious liberalism. Meanwhile, The Star's portal scarcely shows its readers agree to religious liberalization.

Meanwhile, Hanafiah and Yusoff (2015) found that Malay leaders, distinguished scholars, community figures and most Muslims of Malaysia agreed to universally reject the "I Want to Touch a Dog" activity. This sensitive program invites liberated people including local Muslims to touch dogs whereas the intentional act is undoubtedly recognized as an apparent attempt to underestimate the consistent practice of Muslims in Malaysia which traditionally prohibits them from accidentally playing with that animal. 
Research report conducted by Nordin et. al (2012) titled Religious Liberalism in Analysis of Sisters in Islam Discourse in Malaysia found that religious liberalism strived by this social movement has convincingly demonstrated a bad influence to civil society. As such, the National Fatwa Council in 2006 has endorsed this holding as a misguided basis based on the fundamental principle of custody the religion and the policy of minimum (hirasat al-din wa 'imarat al-dunya) in the legitimate rules (siyasah syar'iyyah).

Tatar and Majid (2012) writes professionally about the Understanding of Middle Class Islam Women's in the Klang Valley Against Liberal Islam found that the level of understanding of Liberal Islamism by middle-class women working collaboratively as lawyers, lecturers and teachers in the Klang Valley is at moderate level. This situation is a sign of liberalism ideology can sneak in the minds of the Muslim community, though it requires a little time.

The study by Saleh (2010) on the Interpretation Method and Translations of Quranic Verses By Sisters in Islam (SIS) and Liberal Islam Network (JIL): Comparison With Ulama Tafsir shows that there is precisely a direct conflict of interpretation between ulama tafsir with SIS and JIL because of logical intellect understanding uses freely. The logical approached is absolutely foreign to the methodology employed by the scholars of interpretation.

\section{Methodology}

The paper is employing a qualitative approach using exploratory case studies. In total, this article universally refers to primary and secondary sources with authoritative forms of Western and Islamic scholars, articles, theses, newspapers and books. Liberalism related websites were also a reference material for obtaining detailed information about them. The data obtained were collected using the textual technique. Textual methods are chosen wisely to illuminate and make interpretations based on selected writings. To accurately analyze qualitative data, a descriptive method approach is universally used.

\section{Literature Review Analysis}

Topics on literature review related to liberalism are discussed in many published articles. However, all the articles are more focused on specific issues. In fact, the discussions are focused solely on issues of Liberal Islam, religious feminism, religious pluralism and modernism. While a particular study of the acceptance and rejection of Muslims towards liberalism has been unset aside and placed in a study. Based on the above-mentioned research questions, this study is conducted to answer the objectives to be achieved.

This article divides the literature into four particular themes. First, a literature review on the concept of liberalism. Second, literature review on the acceptance of liberal ideology. Third, literature review on the rejection of ideology of liberalism in the Islamic world. Fourth, the literature review on the views of Islamic scholars on the ideology of liberalism. 


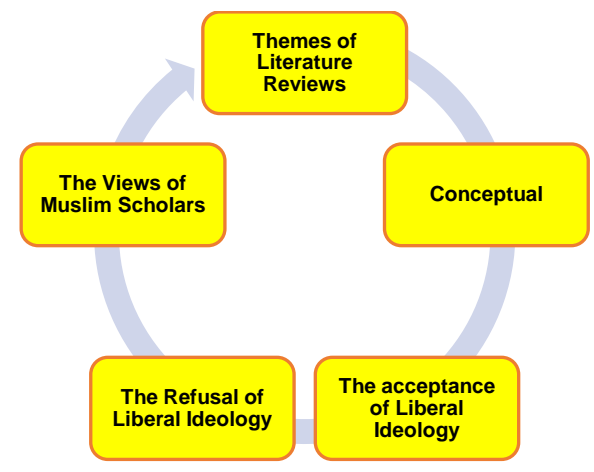

Figure 1: Literature Review of Liberalism Themes

Some recent studies give different definitions of the concept of liberalism. Among them are:

Sannusi \& Semah (2018) in their article entitled "Framing Issues of Religious Liberalism" exposes the concept of liberalism. According to them, the term liberalism is interpreted as an act of disregarding religion, disliking the practice of religion and refusing to accept laws considered to be a violation of human rights.

Ramli (2012) in his book entitled "The Dangers of Liberalism and Religious Pluralism against the Muslim Belief" succinctly summarizes the concept of liberalism as an ideology that aims to dispel religious holdings between man and God. To achieve this goal, the liberal group eagerly sought to intentionally break free from the specific rule of divine revelation, to be suspicious of the favorable opinions of Islamic scholars, to eradicate the fundamental teachings of the ancient clergy, to liberally interpret religions in the modern patterns and to adjust their religion according to common sense, despite their actions, contrary to shariah.

Muammar (2009) in his book entitled "On the Critical Response Right of the Liberal Islamic Discourse" uniquely defines liberalism as a lifestyle that influences a person to the fundamental principle that he is free to make ultimate decisions without undoubtedly having to willingly accept the possible objections of any party whether the objection from religious, cultural, custom and community. All of them possess no authority to object to the decisions made by the individual even though they are solely personal. The definition of religion is adapted to the Western understanding that religion represent merely a teaching, a fairy tale and an irrational hold.

In conclusion, liberalism undoubtedly represents a modern belief that progressively eliminates religious aspects, promptly rejects the fundamental views of Islamic scholars and naturally adapts western thinking to practical life. 


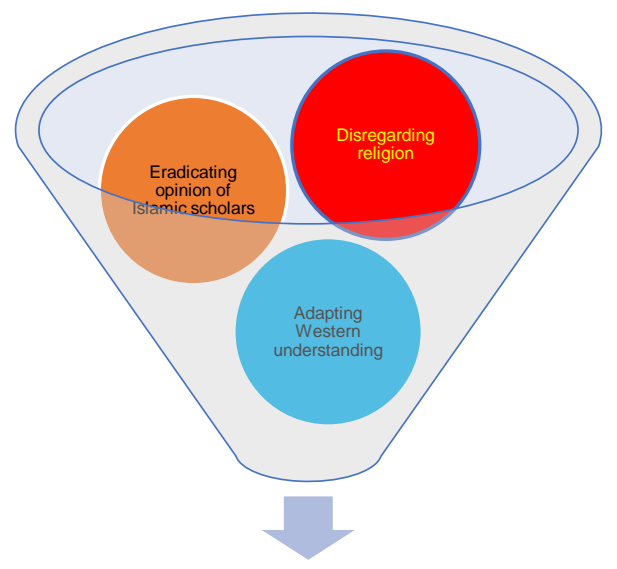

Figure 2: The Definition of Liberalism

\section{The Acceptance of Liberalism}

Yama et. al (2018) in his article entitled "The Use of Prophet's Hadith in Writing: An Analysis of Liberal Works and Their Influence on Social Media" has revealed the tendency of liberalists in Islamic countries to manipulate social media as a fertile field to powerfully influence society. This comprehensive approach is implemented because of the increasing number of netizens who tend to consume social media such as facebook and blogs. Many of the issues that were circulated were to dispute the position of the hadith. Among them are the events of Isra 'Mikraj, female genitalia, heresy, the miracle of the broken moon is false and untrue gold and silk cannot be worn by a man.

Saleh et. al (2017) in her study entitled "The Influence of Liberal Thought on Social Media" exposed some funded groups that spread liberalism through social medium such as twitter, facebook and page. The groups target the youth to be influenced since they acquire a network to impart this knowledge with their friends. Among the key drivers of the websites that promote this liberal doctrine are the Universal Muslim Community (KMU), the Dialog Project, the Dubook Press and the Youth Movement for Malaysia. These social websites are financially supported through funds from the West.

Rahman (2016); Pătulea, Marin-Pantelescu, (2018) in his article entitled "The Influence of Liberal Islamic Thought on Anti-Hadith" describes the acceptability of ideas brought by the pre- and postindependence modernist movements and influencing the changing thinking that some Malaysians want to practice. . The author has listed influential figures and organizations such as Syed Akbar Ali, Zainah Anwar, Astora Jabat, Musawah Society, and Islamic Quran Society, Sisters in Islam (SIS), Inter Faith Commision (IFC), Women's Aid Organization (WAO), All Women's Action Society (AWAM) and The Joint Action Group for Gender Equality (JAG). 
Rahim \& Amran (2016), entitled "Liberal Islamic Understanding in Dialogue Projects: Literature Studies", says a group of local youths are fighting for human rights in terms of gender equality, feminism, religious pluralism and secularism. Principal focus is also on the acceptance of liberalization in four concepts - divine revelation, da'wa, akidah and shariah. This liberalization could pose a threat to Malaysian Muslims as the individuals who fought for it included influential people like Marina Mahathir, Faisal Tehrani, Fuad Rahmat and Benz Ali.

Duereh's study (2013) entitled "Analysis of Religious Liberalism in Malaysia According to the Islamic Faith Perspective" tries to explain about modern liberalism in terms of faith. The study found religious liberalization in Malaysia is at a critical stage. Through the data collected, some respondents did not recognize the Prophet Muhammad as the Messenger of God. Respondents also fight for the possible freedom of the Muslim individual to apostate and the religious authorities have no right to prevent anybody from apostasy. They also accept religious pluralism as a solution to promote harmony to all religion followers. In fact, the respondents rejected the hudud law because they believed that was an ancient legislation and it is inappropriate to modern practice in recent days.

Puji (2013) in her study entitled "Liberal Islamic Critique of Qur'anic Interpretation: Focus of Study on Some Issues in the Qur'anic Studies" encompasses the concept of divine revelation, copy and replicated (nasakh wa mansukh) and cause of descent (asbab al-nuzul). The selected individuals who served as respondents to this study were drawn from Malaysia, Syria and Jordan. The results show that Liberal Islamic supporters have misunderstood the concept of revelation, nasakh mansukh and asbab al-nuzul. They say that divine revelation and the Quran are cultural tools. Whereas nasakh mansukh and asbab al-nuzul contain nonsense and difficult to adequately understand. Therefore, the Quran naturally needs to be reinterpreted.

From the above literature, it is discovered that the acceptance of liberalism among the Muslim community has its roots. Among the most endangered aspects of this liberalism are the Quran and its exegesis, hadith and its interpretation, Islamic faith, divine law and morals. Liberalization of all this caused the Muslim community to abandon its teachings gradually.

\section{The Rejection of Liberalism}

A study by Zainol (2018) entitled "Liberal Thought Threats Against the Beliefs of Sunnah Wal Jamaat Believers" states that liberals support homosexual activity and are considered born of genetics. Therefore, homosexuality represents a gift from God. This kind of relationship should be acceptable and be unpoliticized. Not considered inverse in modern society. However, the author rejects this causal relationship as a result of genetics and divine providence. On the other hand, the significant cause of considered homosexuality is due to the cultural influence of environmental life and not genetic factors. 
A study by Mohamad et.al (2017) entitled "Interfaith Commission Malaysia: An Analysis of Its Establishment in Realizing Religious Harmony in Malaysia" states that the religious department must take the initiative to solve religious conflicts following its establishment policy that would undermine the Islamic religion in this country. For example, Islamic law that is enforced, has interfered with human rights and freedoms. As well known, most of the IFC's membership is in favor of liberalism.

Rahim et. al. (2016) in an article entitled "Liberal Islam and its Threats to the Survival of Sunnis in Malaysia" discusses organizations that support Liberal Islamic movements such as the Sister in Islam (SIS), the Institute for Policy Studies (IKD), the Middle Eastern Study Group and Forum Iqra. All the movers of this Liberal Islamic movement contain some similarities in a way. Among them, lacked in-depth religious education, scholars tied to British thought heritage, interested in philosophy, received foreign funding and embraced an agenda to resolve the deficiencies in society.

Sulong (2016) in his article entitled "Preserving the Islamic Faith: An Analysis of the Law and Fatwa in Penang" points out that the origins of faith abuses caused by Muslim became minority in the political, social and liberal elements of monopolizing Muslims. Thus, in order to control the profanity of the faith, the author has laid down guidelines from scholars such as jihad, committing suicide for those who claim to be the apostles or representatives of the gods, combating heresy and suppressing evils such as apostasy by practicing hudud or takzir law. All of these suggestions are against the wishes of the liberalists.

Dagang et.al (2015) study entitled "Threatening Liberal Islamic Thought to Muslims in the Archipelago: A Review" discusses the comprehensive ban on religious liberalism by the 74th National Committee on Islamic Religious Affairs Malaysia. Even though the fatwa forbade it, the mindset still threatened Muslims. Therefore, vigorous efforts should be developed to curb abuses of the faith and sharia brought by the supporters of liberalism. The necessary disclosures and accurate descriptions of the issues they bring should also be explained in detail so that the aware public can properly understand and not be caught up in the key issue.

Salleh et.al (2015) in his article entitled "Opposition to the Agenda of Feminism and Liberalism in Malaysia" exactly describes the rejection of liberalism based on campaigns, seminars, books, Islamic and Malay portals, Malaysia Today and Malaysia Insider. The crucial topic of discussion in this study is to make the Muslim community sensitive to women's personality so that it is not easily influenced by the feminist agenda in carried by liberalism. This is necessary because the ultimate fate of a country lies in the hands of women. If women are damaged then the ummah will also be damaged.

Alam (2013) in his study "Analyzes on Liberalism and Modernism" explains the difference between the reforms brought by liberalism and the reforms brought by Islamic mujaddids such 
as 'Umar bin' Abd al-Aziz, Imam al-Shafi'I, Iman Ahmad Ibn Hanbal, Imam Abu Hasan al-Ashaari, Imam al-Ghazzali and Hasan al-Banna. He found the reformations brought by Islamic mujaddids in accordance with Islamic principles while in the flow of liberalism reformations are in the rational sense. It must be rejected because there was a conflict with Islamic creed and sharia.

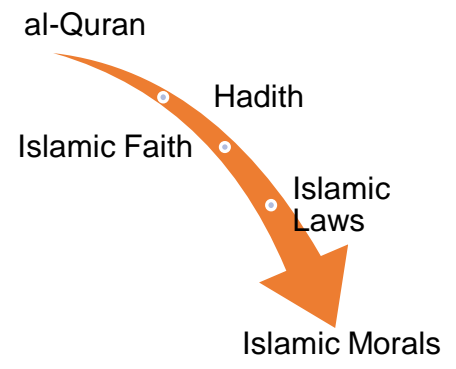

Figure 3: Most Endangered Aspects of Liberalisme

\section{Perspectives of Muslim Scholars' on Liberalism}

Islamic scholars have expressed their views on liberalism. These are:

The Negeri Sembilan Mufti Department (2017) has issued a fatwa banning books containing antihadith elements. The banned books are "Hadith Answers to Critics", "Disclosures of Truth Are from your God-hadiths in the Quran", "Readings", "The Computer Speaks-Lam Message to The World" and "the Iqra Brochures". All of these books are banned for containing information contrary to Islamic creed, sharia and morals. Therefore, anyone who practices its contents is considered a heretic.

The Department of Islamic Development Malaysia (2015) in a book entitled "Compilation of Legal Opinions of the National Council's Fatwa Committee on Islamic Religious Affairs Malaysia" has discussed the flow of liberal thought from the legal perspective and its impact on Islam in Malaysia. Liberalism was decidedly a heresy and deviated from Islam from the point of faith and sharia. The abuses that occur in the aspects of faith are like religious pluralism, the human mind is a revelation and doubts the purity of the Quran. Such deviations from the Shariah aspects as disputing Quranic interpretations and hadiths, making new interpretations of worship, disputing the criteria and morals of the prophet, rejecting the discipline of Islamic science and condemning it in its own way.

Mohamad (2015) argues that liberalism is a deviation from the Islamic foundation. This understanding allows the name of Allah Almighty to be used by non-Muslims, impersonate all religions, all religions are true, apostates are human rights, defend heresy by reason of freedom of thought, newborns do not need to be religious until 18 years old, calling for the abolition of 
Sharia law, LGBT people are free to practice sexual orientation and non-Muslims have the right to spread their religion to Muslims.

The Selangor State Mufti Department (2014) has issued a fatwa on the notion that liberalism and religious pluralism are deviant and deviate from Islamic teachings. This fatwa is addressed to Sisters in Islam forums, individuals and organizations who advocate liberal ideologies in Malaysia. Publications containing liberalism and religious pluralism are banned. Individuals who adhere to liberalism and religious pluralism are asked to repent and return to the true teachings of Islam.
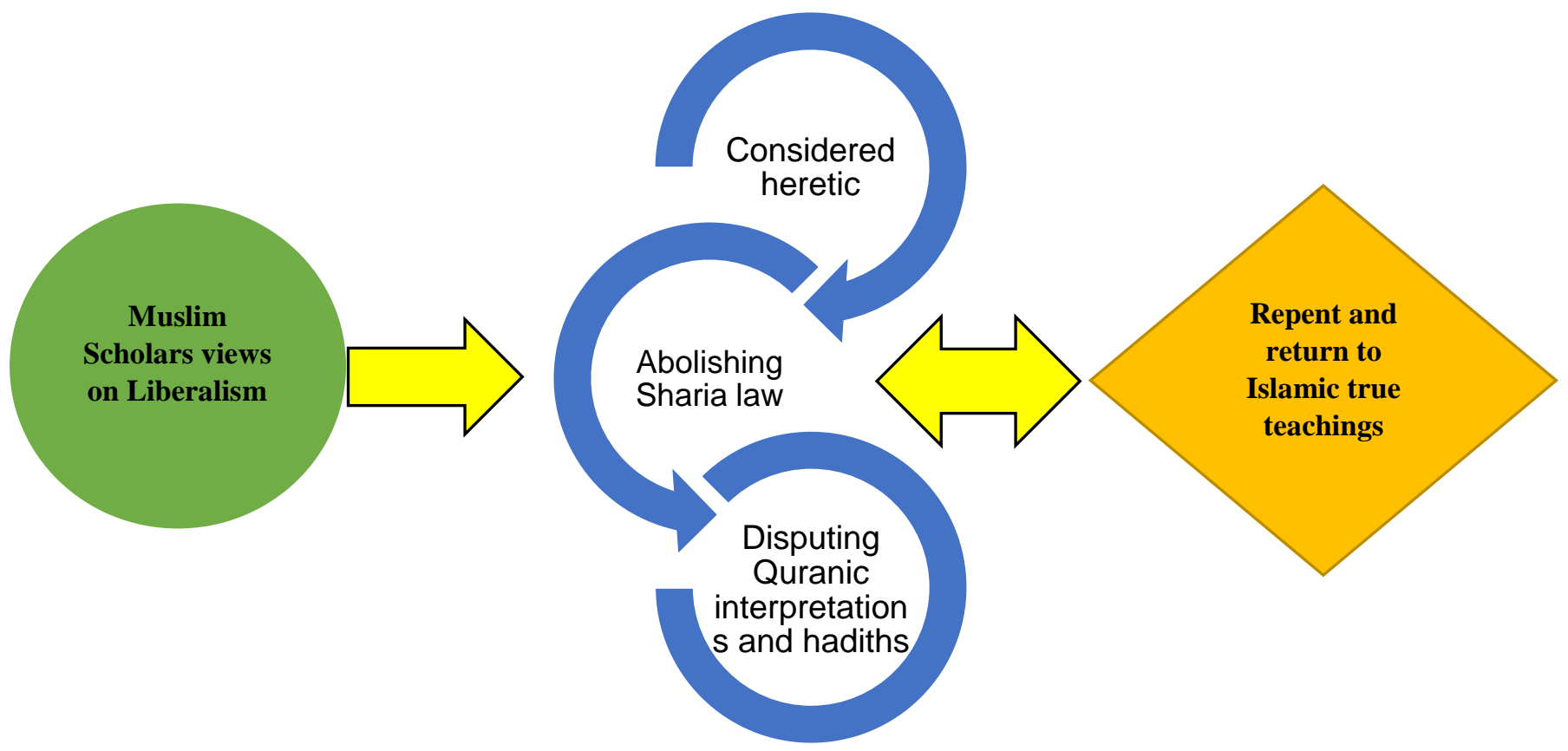

Figure 4 : Perspectives of Muslim Scholars' on Liberalism

\section{Conclusion}

Overall, the literature on liberalism in Muslim world is extensive. Evidence can be found from the writings listed in the literature section through studies that discuss the concept, acceptance, rejection and views of scholars on liberalism. The idea of liberalism jeopardizes the faith of Muslims because this trend is able to loosen the grip of Muslims faith. Based on the literature review, it is found that the development of liberalism in Malaysia specifically is difficult to control and will be a point of endless discussion. 
INTERNATIONAL JOURNAL OF ACADEMIC RESEARCH IN BUSINESS AND SOCIAL SCIENCES

Vol. 9, No. 11, November, 2019, E-ISSN: 2222-6990 @ 2019 HRMARS

Contributors/Acknowledgement: All authors contributed equally to the conception and design of the study. We express our deepest gratitude to Center for Research Excellence \& Incubation Management (CREIM) and Faculty of Islamic Contemporary Studies, Universiti Sultan Zainal Abidin for supporting our intellectual endeavor.

\section{References}

Alam, A. I. Z. (2013). Konsep Tajdid al-Din: Satu Analisis Terhadap Liberalisme dan Modenisme. (Master Degree Thesis- unpublished). Universiti Sains Malaysia.

Ali, M. N. S., \& Ismail, A. M. (2017). Konstruk Pelaporan Pemikiran Isu Liberalisasi Agama Dalam Portal Berita Harian dan The Star. Jurnal Komuniasi. 33(1). 229-241.

Azmi, A. S., \& Ismail, M. Y. (2018). Konsep Rahmatan Lil Alamin Dalam Hadith: Penerokaan Makna Serta Aplikasi di Malaysia. Journal of Hadith Studies. 3(1). 1-13.

Bakhit, M. H. M. (2011). al-Islam fi Muwajahat al-Ghazwu al-Fikr al-Istisyraqi wa al-tabsyiri. Oman: Dār Majdalāwī lil-Nashr wa-al Tawzī.

Browers, M., \& Kurzman, C. (204). An Islamic Reformation. New York: Lexington Books.

Department of Islamic Development Malaysia. (2015). Kompilasi Pandangan Hukum Muzakarah Jawatankuasa Fatwa Majlis Kebangsaan Bagi Hal Ehwal Ugama Islam Malaysia. Putrajaya: Jabatan Kemajuan Islam Malaysia.

Dollah, M. U., Zabit, M. N. M., \& Omar, T. Z. Z. (2018). Comparing the Value of Control with Characteristic of Prediction Conveyed in Mathematics Textbooks in Malaysia and Australia. International Journal of Academic Research in Progressive Education and Development, 7(4), 387-396.

Duereh, M. (2013). Analisis Liberalisme Agama di Malaysia Menurut Perspektif Akidah Islam. (PhD Thesis- unpublished). Universiti Sains Malaysia.

Hanafiah, M. G., \& Yusoff, M. Y. M. (2015). Kontroversi Program I Want to Touch a Dog Dalam Media Kontemporari Daripada Perspektif Melayu. Jurnal Komunikasi. 31(2). 195-210.

Ibrahim, M., Majid, L. A., Awang, J., Kadir, M. N. A., \& Othman, F. M. (2013). Pengajian Islam Di Ipt Malaysia Dalam Menangani Islam Liberal. 5(1), 37-53.

Ismail, W. D., Nasir, M., Syukran, B., \& Ismail, M. (2015). Ancaman Pemikiran Aliran Islam Liberal Kepada Umat Islam di Nusantara: SatuSorotan Kajian. Sains Humanika, 5(3), 77-85.

Kurzman, C. (1998). Liberal Islam A Source Of Book. New York: Oxford University Press.

Majid, L. A., Zin, M. Z. M., Sakat, A. A., Nor, M. R. M., Kasmo, M. A., Kadir, M. N. A., Othman, F. M., Awang, J., \& Ibrahim, M. (2011). Response of Muslim Community Concerning Liberal Islam In Malaysia. Advances in Natural and Applied Sciences, 5(5), 440-445.

Mas'od, M. A. (2012). Serangan Ideologi Barat Terhadap Pemikiran Umat Islam dan Implikasinya Kepada Iman. Jurnal Penyelidikan Islam, 25, 99-118. URL http://www.myjurnal.my/filebank/publishedarticle/34227/Article_6.PDF. Surfed on $20^{\text {th }}$ July 2019.

Mohamad, A. R., Mamat, S. A., Razif, M. A. M. (2017). Interfaith Commission Malaysia: Analisis Ke Atas Penubuhannya Dalam Merealisasika Keharmonian Agama Di Malaysia, Journal of Islamic Social Sciences and Humanities 11(1), 77-94. 
INTERNATIONAL JOURNAL OF ACADEMIC RESEARCH IN BUSINESS AND SOCIAL SCIENCES

Vol. 9, No. 11, November, 2019, E-ISSN: 2222-6990 @ 2019 HRMARS

Mohamad, Z. (2015). Bayan Linnas Siri 42: G25 dan Isu Khalwat. Diperoleh daripada URL http://muftiwp.gov.my/ms/artikel/bayan-linnas/1823-bayan-linnas-siri-41- g25-dan-isukhalwat?highlight=WyJsaWJlcmFsll0=. Surfed on 20 th July 2019.

Muammar, K. (2009). Atas Nama Kebenaran Tanggapan Kritis Terhadap Wacana Islam Liberal. Selangor: Universiti Kebangsaan Malaysia.

Negeri Sembilan Mufti Department. (2017). Fatwa Golongan Anti Hadith. Diperoleh daripada URL http://e-smaf.islam.gov.my/ surfed on 20th July 2019.

Nordin, M. Z. F., Abdullah, S., \& Mansor, M. (2012). Liberalism Agama Dalam Analisis Wacana Sisters in Islam di Malaysia. Eserach Report. Universiti Utara Malaysia.

Pătulea, D. M., Marin-Pantelescu, A. (2018). Exploratory Research in the Tertiary Sector: Romanian Preferences for Cultural Services, International Journal of Academic Research in Accounting, Finance and Management Sciences 8 (3): 83-94, http://dx.doi.org/10.6007/IJARAFMS/v8-i3/4532 (DOI: 10.6007/IJARAFMS/v8- i3/4532)

Puji, T. I. Z. (2013). Kritikan Islam Liberal Terhadap Pentafsiran al- Qur'an. (PhD Thesisunpublished). Universiti Kebangsaan Malaysia.

Rahim, A. S. M. A. \& Amran, N. N. (Eds.) (2016). Prosiding Kolokium Penyelidikan Siswazah Jabatan Pengajian al-Quran \& al-Sunnah 2016: Fahaman Islam Liberal Dalam Projek Dialog: Kajian Literatur. Bangi, Selangor: Univeriti Kebangsaan Malaysia

Rahim, R. A. A., Jalal, A. F. A. \& Rosele, M. I. (2016). Islam Liberal dan Ancamannya Terhadap Kelangsungan Ahli Sunnah Waljama'ah di Malaysia. DIm. Muhammad Yusuf Khalid, Syamsul Bahri Andi Galigo \& Mohd Muslihuddin Syah Haji Mustafa (pnyt.), Sumbangan Ahli Sunnah Waljama'ah di Alam Melayu (hlm. 17-50). Negeri Sembilan: Penerbit Universiti Sains Islam Malaysia.

Rahman, K. A. A. (2016). Pengaruh Pemikiran Islam Liberal Dalam Fahaman Anti Hadis. $15^{\text {th }}$ November 2017, International Islamic University College Selangor, Bandar Seri Putra, Malaysia. Organized by Hadith Research Institute (Institut Kajian Hadith INHAD).

Ramli, W. A. W. (2012). Bahaya Liberalisme dan Pluralisme Agama Terhadap Akidah Belia Muslim. Johor Bharu: Majlis Agama Islam Negeri Johor.

Saleh, M. F. M. (2010). Metodologi Tafsiran Dan Terjemahan Ayat Al-Quran Oleh Sisters In Islam (SIS) Dan Jaringan Islam Liberal (JIL): Perbandingannya Dengan Ulama Tafsir. (Master Degree Thesis- unpublished). Universiti Kebangsaan Malaysia.

Sannusi, S. N., \& Seman, N. (2018). Pembingkaian Isu Liberalisme Agama Dalam Portal Berita di Malaysia. Jurnal Sains Sosial dan Kemanusiaan, 13(1), 1-17.

Sulong, J. (2016). Pemeliharaan Akidah Islam: Analisis Daripada Sudut Penguatkuasaan UndangUndang dan Fatwa di Pulau Pinang. Jurnal Akidah \& Pemikiran Islam, 18, 1- 34.

Tatar, A., \& Majid, L. A. (2012). Kefahaman Wanita Islam Kelas Menengah di Lembah Klang Terhadap Islam Liberal. Jurnal Islamiyyat, 34, 13-25.

Yama, P., Salleh, N. M., Ismail, A. Z., Husin, H. M.,. Haridi, H. M. \& Noor, M. S. M. (2018). Penggunaan Hadith Nabi Dalam Penulisan: Analisis Terhadap Karya Karya Golongan Liberal Dan Pengaruhnya Dalam Media Sosial. Journal of Hadith Studies. 3(1). 1-9. 
Zainol, N. Z. N. (2018). Ancaman Aliran Pemikiran Liberal Terhadap Akidah Ahli Sunnah Wal Jamaah. Persidangan Antarabangsa Pemikiran Islam. Parit Raja, Johor September 2018.

Zarif, M. M. M., \& Abdullah, W. H. (2015). Kedudukan dan Peranan Hadis Dalam Terjemahan Liberalisme Terhadap al-Quran al-Karim in Khadher Ahmad, Faisal Ahmad Shah \& Monika @ Munirah Abd Razzak (Ed.), Salah Faham Terhadap Sunnah Isu dan Penyelesaian (pp. 2542). Kuala Lumpur: Universiti Malaya. 